\title{
Techno-economic analysis comparison of comminution of wood chips using a hammer mill and a rotary shear
}

\author{
Damon S. Hartley ${ }^{1}$, Christopher Lanning ${ }^{2}$ and \\ James Dooley $^{2}$ \\ 1 Idaho National Laboratory, Idaho Falls, ID \\ 2 Forest Concepts, Auburn, WA
}

October, 2016

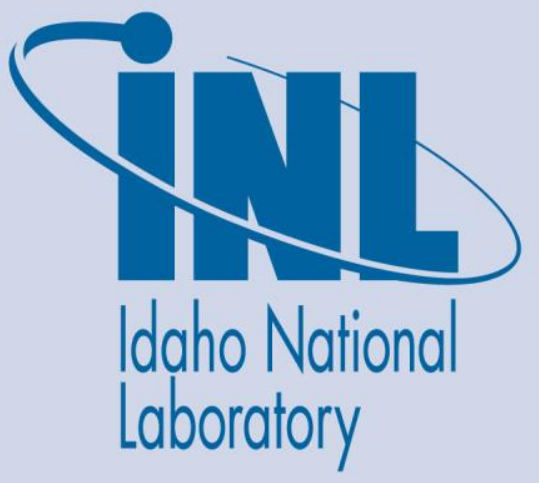

The INL is a U.S. Department of Energy National Laboratory operated by Battelle Energy Alliance 


\section{DISCLAIMER}

This information was prepared as an account of work sponsored by an agency of the U.S. Government. Neither the U.S. Government nor any agency thereof, nor any of their employees, makes any warranty, expressed or implied, or assumes any legal liability or responsibility for the accuracy, completeness, or usefulness, of any information, apparatus, product, or process disclosed, or represents that its use would not infringe privately owned rights. References herein to any specific commercial product, process, or service by trade name, trade mark, manufacturer, or otherwise, does not necessarily constitute or imply its endorsement, recommendation, or favoring by the U.S. Government or any agency thereof. The views and opinions of authors expressed herein do not necessarily state or reflect those of the U.S. Government or any agency thereof. 


\title{
Techno-economic analysis comparison of comminution of wood chips using a hammer mill and a rotary shear
}

\author{
Damon S. Hartley, Christopher Lanning and James Dooley
}

Error! Reference source not found.

\begin{abstract}
Idaho National Laboratory
Biofuels and Renewable Energy Technology Department

PO Box 1625

Idaho Falls, Idaho 83415
\end{abstract}

http://www.inl.gov 



\section{Table of Contents}

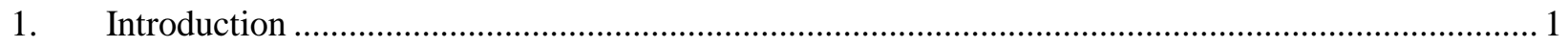

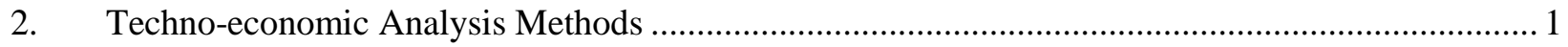

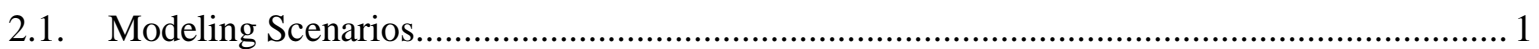

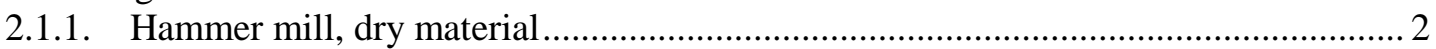

2.1.2. Hammer mill, wet material ................................................................................... 2

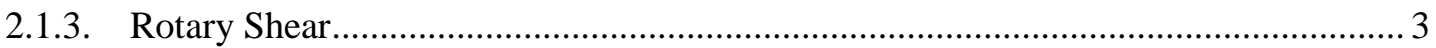

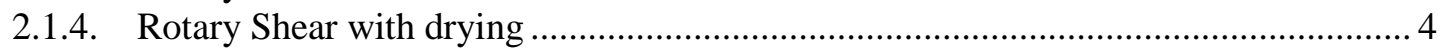

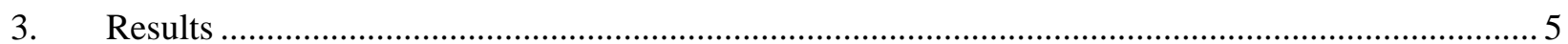




\section{List of Figures}

Fig 1. Block flow diagram of the hammer mill, dry material scenario, green ovals provide material properties and yellow blocks represent equipment................................................

Fig 2. Block flow diagram of the hammer mill, wet material scenario, green ovals provide material properties and yellow blocks represent equipment .................................................... 3

Fig 3. Block flow diagram of the rotary shear scenario, green ovals provide material properties

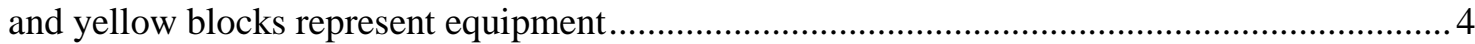

Fig 4. Block flow diagram of the rotary shear with drying scenario, green ovals provide material properties and yellow blocks represent equipment................................................................. 


\section{List of Tables}

Table 1. Hammer Mill, dry material equipment parameters ................................................................... 2

Table 2. Hammer mill, dry material equipment parameters .................................................................... 3

Table 3. Rotary shear scenario equipment parameters...........................................................................

Table 4. Rotary shear with drying scenario equipment parameters .........................................................5

Table 5. Cost summary for Hammer mill, dry material ............................................................................5

Table 6. Cost summary for Hammer mill, wet material .......................................................................... 6

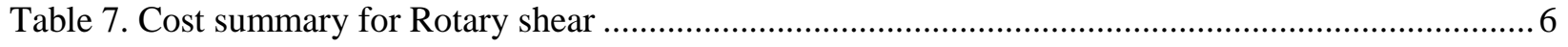

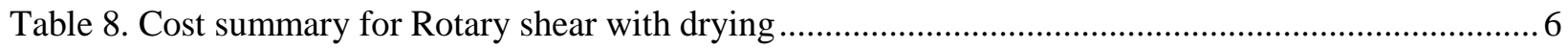




\section{Introduction}

Preprocessing is a crucial step in the utilization of biomass feedstocks for the production of fuel and biomaterials. Size reduction and drying of the material, where used, are two of the most costly and energy intensive operations that are undertaken during preprocessing, reduction of the energy usage during these two phases will reduce cost of processing and ultimately reduce the overall cost to the final user. In effort to lower the cost for size reduction, Forest Concept, LLC has developed a rotary shear, for the comminution of biomass feedstocks, that they have called the "Crumbler". The "Crumbler" utilizes interlocking, rotating disk that shear the material rather than using impact to reduce the particle size of the materials.

\section{Techno-economic Analysis Methods}

The Biomass Logistics Model (BLM) was used to perform the techno-economic analysis for this project. The BLM incorporates information from a collection of databases that provide (1) engineering performance data for hundreds of equipment systems, (2) spatially explicit labor cost datasets, and (3) local tax and regulation data. The BLM's analytic engine is built in the systems dynamics software package Powersim ${ }^{\mathrm{TM}}$. The BLM is designed to work with thermochemical and biochemical-based biofuel conversion platforms and to accommodate a range of lignocellulosic biomass types (e.g., agriculture residues, short-rotation woody and herbaceous energy crops, woody residues, and algae). BLM simulates the flow of biomass through the entire supply chain, while tracking changes in feedstock characteristics (i.e., moisture content, dry matter, ash content, and dry bulk density) resulting from interactions along the supply chain (Cafferty et al. 2013). The model accounts for all the equipment that comes into contact with the feedstock from the time that it is harvested up to the point where the material enters the conversion reactor. Tracking the machine interactions along with the associated property changes allows for highly detailed economic cost and energy consumption analyses. Additionally, the results from the BLM can be used as inputs to additional models that are used to provide indications of sustainability or material quality. The process information for all equipment, excluding the comminution equipment, is based on data collected from the Process Demonstration Unit within the Biomass Feedstock National User Facility located at the Idaho National Laboratory. The information on comminution energy and throughput for both the hammer mill and rotary shear, was provided by Forest Concept, LLC.

\subsection{Modeling Scenarios}

This techno-economic analysis is limited to the secondary size reduction operations that occur when feeding wood chips into a biochemical or thermochemical conversion process. The economic calculations cover the operations of these processes only and do not consider differences that may arise in the supply chain beyond the border of the secondary size reduction operation. It is assumed that each scenario is processing enough material to produce 800,000 dry short tons per year or 95 dry short tons per hour. The individual equipment in the model have operating capacities less than 95 dry short tons per hour, necessitating that multiples of each type is used to reach the required capacity. The basis for comparison between the operational scenarios is total cost in dollars per dry U.S. short ton. Each scenario begins with the same feedstock material, pulp quality wood chips (approximately 1 in $\mathrm{x} 1 \mathrm{in}$, $50 \%$ moisture content (MC) wet basis (w.b)). The chips are conveyed to the secondary size reduction processes from a storage pile. After conveyance each scenario differs in the order of the processing operations and the equipment used. 


\subsubsection{Hammer mill, dry material}

This Hammer mill, dry material scenario represents the most common method of secondary size reduction utilized for wood chips. The process is depicted in fig 1. In this scenario, the chip material is conveyed to a rotary dryer where the material is dried to $6 \% \mathrm{MC}$ w.b.. The dried material is conveyed to a hammer mill fitted with a 1.5 inch opening grate, where it is ground. The material that leaves the grinder is screened, with material meeting the size specification continuing through the process, oversized material recirculated back to the hammer mill and fines are disposed. The material that continues from the hammer mill is then placed in covered storage to await feeding to the conversion reactor. Table 1 gives the parameters used for each piece of equipment.

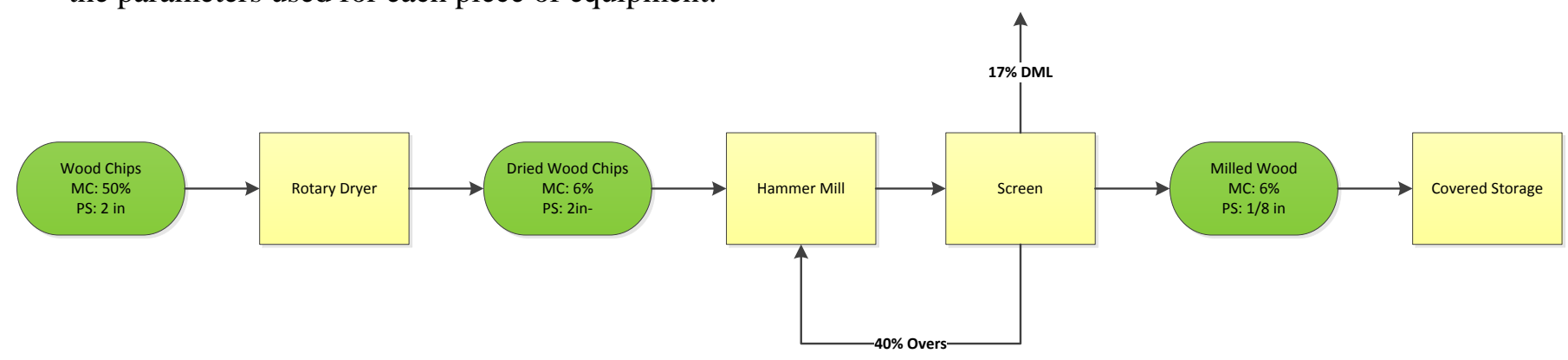

Fig 1. Block flow diagram of the hammer mill, dry material scenario, green ovals provide material properties and yellow blocks represent equipment.

Table 1. Hammer Mill, dry material equipment parameters

Rotary Dryer Hammer Mill Vibratory Screen

Purchase Price (2014 USD)

$\$ 351,000$

$\$ 113,483$

$\$ 75,000$

Energy Consumption (kWh/dry ton)

360

19.24

1.39

Capacity (dry ton/hr)

4.8

5.0

5.0

Pct. of material oversized

$-$

$40 \%$

Pct. fines

$-$

$-\quad 17 \%$

Throughput (dry ton/ hr)

4.8

2.0

2.0

\subsubsection{Hammer mill, wet material}

The process for the hammer mill, wet material is presented in the block flow diagram in fig 2 . The chip material is conveyed directly to the hammer mill that is fitted with a 1.5 inch opening grate. The ground material is screened with the material that meets the desired size range continuing through the process, oversized material is recirculated back to the grinder and fines are removed. The material that meets the size specifications is then placed into covered storage to await feeding to the conversion reactor. It is assumed that the moisture content of the material will be reduced by approximately $5 \%$, through grinding Table 2 gives the parameters used for each piece of equipment in the scenario. 


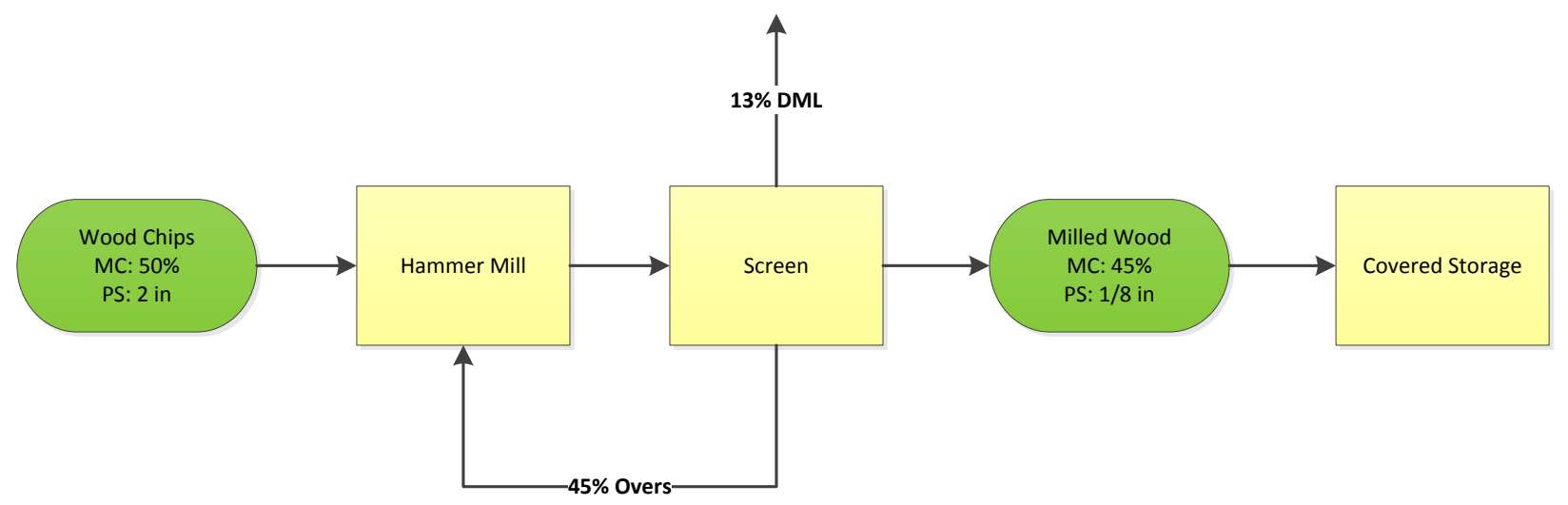

Fig 2. Block flow diagram of the hammer mill, wet material scenario, green ovals provide material properties and yellow blocks represent equipment

Table 2. Hammer mill, dry material equipment parameters

Hammer Mill Vibratory Screen

Purchase Price (2014 USD)

$\$ 113,483 \quad \$ 75,000$

Energy Consumption (kWh/dry ton)

39.83

1.48

Capacity (dry ton/ hr)

5.0

Pct. of material oversized

$45 \%$

Pct. fines

$13 \%$

Throughput (dry ton/hr)

2.0

2.0

\subsubsection{Rotary Shear}

The process that is assumed for secondary size reduction using the rotary shear is presented in Fig 3 . The rotary shear process is essentially identical to the hammer mill, wet material scenario, but the hammer mill is replaced by the rotary shear. The chips are conveyed to the rotary shear, where they are size reduced. The outfeed of the rotary shear delivers the processed material to the screen where the material that meets the design specifications continues on to covered storage. The screened material that is oversize is recirculated back to the rotary shear, while the undersized fine material is discarded. 


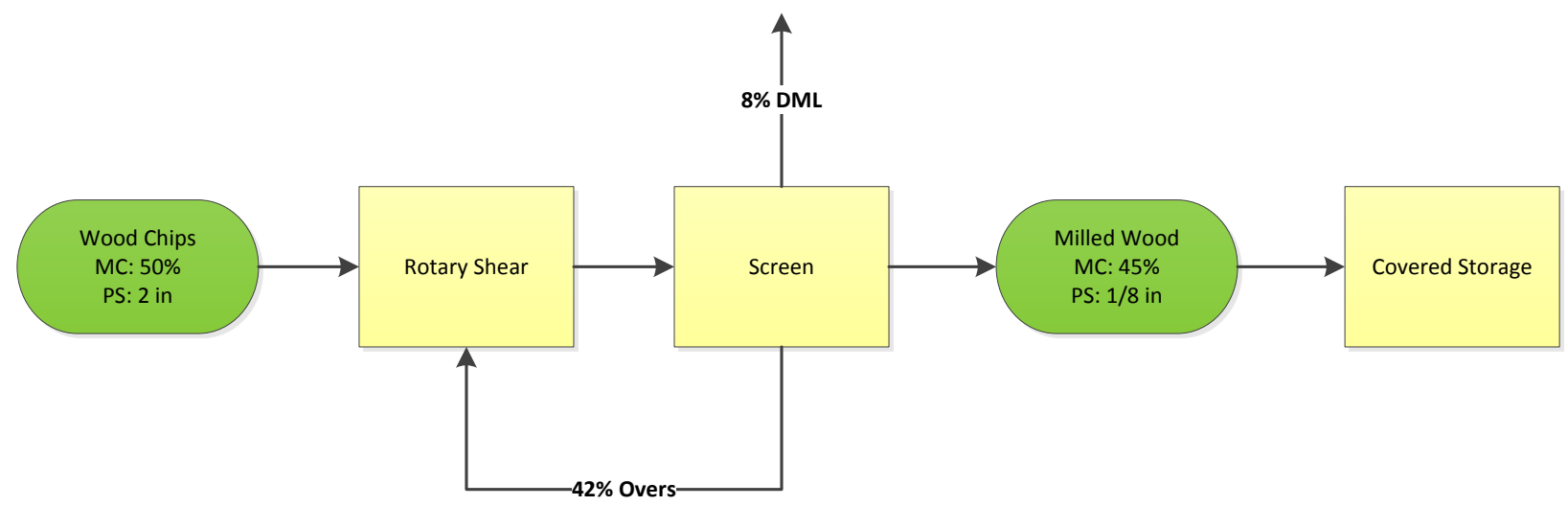

Fig 3. Block flow diagram of the rotary shear scenario, green ovals provide material properties and yellow blocks represent equipment

Table 3. Rotary shear scenario equipment parameters

Rotary Shear Vibratory Screen

\begin{tabular}{lcc} 
Purchase Price (2014 USD) & $\$ 750,000$ & $\$ 145,000$ \\
Energy Consumption (kWh/dry ton) & 39.83 & .80 \\
Capacity (dry ton/hr) & 15 & 15 \\
Pct. of material oversized & - & $42 \%$ \\
Pct. fines & - & $8 \%$ \\
Throughput (dry ton/ hr) & 7.5 & 7.5 \\
\hline \hline
\end{tabular}

\subsubsection{Rotary Shear with drying}

The process that is assumed for secondary size reduction using the rotary shear is presented in Fig 3 . The rotary shear process is essentially identical to the hammer mill, wet material scenario, but the hammer mill is replaced by the rotary shear. The chips are conveyed to the rotary shear, where they are size reduced. The outfeed of the rotary shear delivers the processed material to the screen where the material that meets the design specifications continues on to a rotary drier where the material is dried to 6\% $\mathrm{MC}$ w.b. The screened material that is oversize is recirculated back to the rotary shear, while the undersized fine material is discarded. 


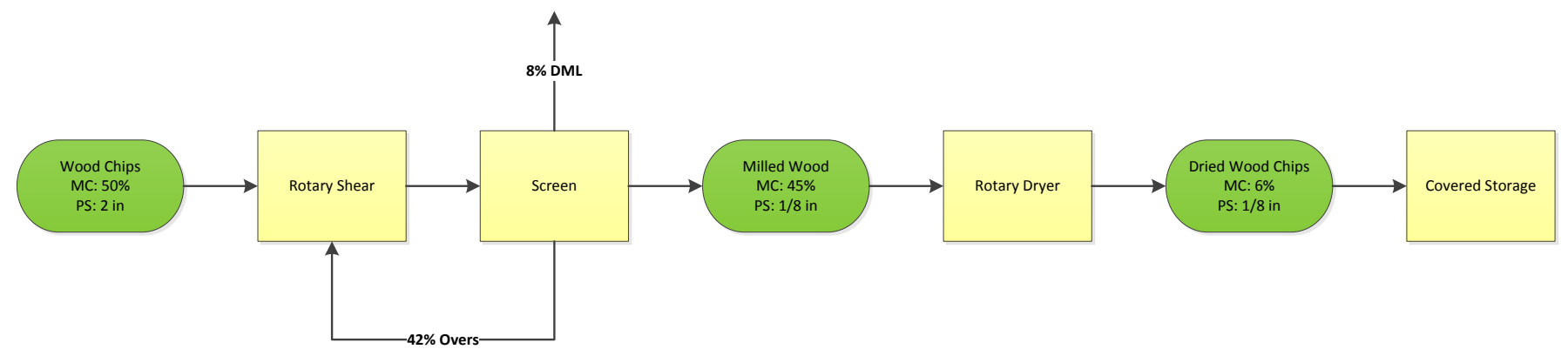

Fig 4. Block flow diagram of the rotary shear with drying scenario, green ovals provide material properties and yellow blocks represent equipment

Table 4. Rotary shear with drying scenario equipment parameters

\begin{tabular}{|c|c|c|}
\hline & $\begin{array}{c}\text { Rotary Shear } \\
\text { \&Screen }\end{array}$ & Rotary Drier \\
\hline Purchase Price (2014 USD) & $\$ 895,000$ & $\$ 351,000$ \\
\hline Energy Consumption (kWh/dry ton) & 40.63 & $288^{\mathrm{a}}$ \\
\hline Capacity (dry ton/hr) & 15 & 4.8 \\
\hline Pct. of material oversized & $42 \%$ & - \\
\hline Pct. fines & $8 \%$ & - \\
\hline Throughput (dry ton/ hr) & 7.5 & 4.8 \\
\hline
\end{tabular}

\section{Results}

Table 5. Cost summary for Hammer mill, dry material

\begin{tabular}{ccccc}
\hline Equipment & $\begin{array}{c}\text { Ownership Cost } \\
(\$ / \text { dry ton })\end{array}$ & $\begin{array}{c}\text { Operating Cost } \\
(\$ / \text { dry ton })\end{array}$ & $\begin{array}{c}\text { Lost Material Cost } \\
(\$ / \text { dry ton })\end{array}$ & $\begin{array}{c}\text { Total Cost } \\
(\$ / \text { dry ton })\end{array}$ \\
\hline Dryer & 0.88 & 8.13 & 0 & 9.01 \\
Hammer mill \& & 1.73 & 7.10 & 8.69 & 17.52 \\
Screen & 0.04 & 0.02 & 0 & 0.06 \\
Conveyors & 0.18 & 0.66 & 0 & 0.84 \\
Dust Collection & & & & $\mathbf{2 7 . 4 3}$ \\
\hline Total & $\mathbf{2 . 8 3}$ & $\mathbf{1 5 . 9 1}$ & $\mathbf{8 . 6 9}$ &
\end{tabular}


Table 6. Cost summary for Hammer mill, wet material

\begin{tabular}{ccccc}
\hline Equipment & $\begin{array}{c}\text { Ownership Cost } \\
(\$ / \text { dry ton })\end{array}$ & $\begin{array}{c}\text { Operating Cost } \\
\text { (\$/dry ton) }\end{array}$ & $\begin{array}{c}\text { Lost Material Cost } \\
\text { (\$/dry ton) }\end{array}$ & $\begin{array}{c}\text { Total Cost } \\
\text { (\$/dry ton) }\end{array}$ \\
\hline $\begin{array}{c}\text { Hammer mill \& } \\
\text { Screen }\end{array}$ & 1.67 & 8.58 & 5.08 & 14.28 \\
$\begin{array}{c}\text { Conveyors } \\
\text { Dust Collection }\end{array}$ & 0.04 & 0.02 & 0 & 0.06 \\
\hline Total & 0.16 & 0.66 & 0 & 0.82 \\
\hline $\mathbf{1 . 8 4}$ & $\mathbf{9 . 2 6}$ & $\mathbf{5 . 0 8}$ & $\mathbf{1 6 . 1 8}$ \\
\hline
\end{tabular}

Table 7. Cost summary for Rotary shear

\begin{tabular}{ccccc}
\hline Equipment & $\begin{array}{c}\text { Ownership Cost } \\
(\$ / \text { dry ton })\end{array}$ & $\begin{array}{c}\text { Operating Cost } \\
(\$ / \text { dry ton })\end{array}$ & $\begin{array}{c}\text { Lost Material Cost } \\
(\$ / \text { dry ton })\end{array}$ & $\begin{array}{c}\text { Total Cost } \\
\text { (\$/dry ton })\end{array}$ \\
\hline $\begin{array}{c}\text { Rotary Shear \& } \\
\text { Screen }\end{array}$ & 1.72 & 3.80 & 2.56 & 8.08 \\
$\begin{array}{c}\text { Conveyors } \\
\text { Dust Collection }\end{array}$ & 0.04 & 0.02 & 0 & 0.06 \\
\hline Total & 0.16 & 0.65 & 0 & 0.81 \\
\hline
\end{tabular}

Table 8. Cost summary for Rotary shear with drying

\begin{tabular}{ccccc}
\hline Equipment & $\begin{array}{c}\text { Ownership Cost } \\
(\$ / \text { dry ton })\end{array}$ & $\begin{array}{c}\text { Operating Cost } \\
\text { (\$/dry ton })\end{array}$ & $\begin{array}{c}\text { Lost Material Cost } \\
\text { (\$/dry ton })\end{array}$ & $\begin{array}{c}\text { Total Cost } \\
\text { (\$/dry ton) }\end{array}$ \\
\hline Dryer & 1.31 & 7.19 & 0 & 8.50 \\
Hammer mill \& & 1.72 & 3.80 & 2.56 & 8.08 \\
Screen & 0.04 & 0.02 & 0 & 0.06 \\
Conveyors & 0.16 & 0.65 & 0 & 0.81 \\
Dust Collection & & & & $\mathbf{1 7 . 4 5}$ \\
\hline Total & $\mathbf{3 . 2 3}$ & $\mathbf{1 1 . 6 6}$ & $\mathbf{2 . 5 6}$ & \\
\hline
\end{tabular}




\section{References}

Cafferty, K.G., Muth, D.J., Jacobson, J.J., Bryden, K.M, 2013a, Model Based Biomass System Design of Feedstock Supply Systems for Bioenergy Production. In: ASME 2013 International Design Engineering Technical Conferences and Computers and Information in Engineering Conference, August 4-7, Portland, OR, USA.

Lanning, D. N., C. J. Lanning, J. H. Dooley and J. C. Slosson (2016). Pathway comparison of comminution energy consumption from wet wood chips to dry sub-mm particles. ASABE Paper No. 245547. 2016 ASABE Annual International Meeting. July 17-20, 2016. Orlando, FL, ASABE. St. Joseph, MI: 18

Lanning, C. J. and J. L. Fridley (2012). Advances in woody biomass drying by taking advantage of surface properties. ASABE Paper No. 12-1337119. St. Joseph, MI, American Society of Biological and Agricultural Engineers: 9 